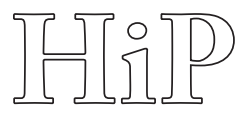

Historia i Polityka

No. $14(21) / 2015$, pp. $67-83$

ISSN 1899-5160

www.hip.umk.pl

DOI: http://dx.doi.org/10.12775/HiP.2015.021

\author{
Andriy GRY BIN KO \\ Ternopil National Economic University, Ukraine
}

\title{
International Interests of Great Britain in the Conditions of the Modern Crisis of the European Security System
}

\begin{abstract}
Strategic approaches and interests of Great Britain in the conditions of the modern crisis of the European security system in connection with the Russian-Ukrainian conflict are analyzed in the article. The historical features of London's policy on the subject of European integration in the field of security are discovered. The author concentrates attention on the reasons of the modern crisis of the European security system. There are revealed the forming factors and the main point of political positions of the EU, the US, NATO, and Great Britain in relation to the military-political aggression of Russia against Ukraine in 2014. The features of the European policy of the British government in the field of security and the strategic interests of Great Britain in the conditions of a renewal of the elements of bloc-civilization conflict are analyzed.
\end{abstract}

Keywords: European security system, USA, NATO, EU, Russia, Ukraine, military-political conflict, Great Britain

In terms of escalation of a permanent diplomatic, cultural-ideological, economic, and military-political confrontation on the European continent and on the vast of Euro-Atlantic cooperation that is directly connected with the deployment of the Russian-Ukrainian conflict in 2014, the European security system as the entire system of international relations entered the period of sharp aggravation of a latent crisis. The confrontation of the powerful geopolitical players, i.e. the key players of the European security (the US, NATO, and the European Union on the one hand, on the other - Russia) not for the first time in the period of the post-bipolar world order has revealed the unsolved problems and failures in the policy of "the Western democracies". Among them we should mention the uncertainty of further development of Euro-Atlantic relations, the role of the US in the furnishing of European security, and potentialities of the European Union in its vain attempts to reach a consensus policy of integration and the ability to become a united center of international politics. For a long time there was no 
adequate strategy of the Western structures in the matter of consequences of the monopolistic position in energy and military-political resources of Russia, that is the consequences of the unconcealed aggressive foreign policy and disregard of the norms of international law.

There is a necessity for analyzing the key features of the foreign policy of this system (the most influential members of the European integration and the EuroAtlantic cooperation, among which a historically important place belongs to the UK) due to the strengthening of the threats for the European security and in relation to the need of its reform in the conditions of the existing renewal of the elements of bloc-civilization conflict. This country has the leading position in Europe in the field of foreign and security policy, as a state that has significant capabilities (extensive network of diplomatic influence, nuclear weapons, modern armed forces and intelligence system that are the best in Europe, a strategic alliance with the US, membership in the UN Security Council and a leading position in NATO, and economic influence) which, under certain circumstances, can form the basis for the development of military-political opportunities in the field of European integration and can provide leadership in the regional integration processes of the country.

In April 2014 Estonian President Toomas Hendrik Ilves, in response to the annexation of Crimea and the preparation for a full-scale military-political aggression of Russia against Ukraine, declared that "a fundamental comprehension of security in Europe is being destroyed nowadays" and that "the political leaders must admit that the old rules don't work anymore". These rules go back to the post-war international relations and the global security system in the conditions of bipolar confrontation, settled in the Helsinki Accords of OSCE in 1975 and modernized in the Charter of Paris for a New Europe in 1990.

Western European countries, which from the late 1940s were developing under political and military protectorate of the United States, have used the opportunity to save resources on creating an exclusively continental security system and have preferred the North-Atlantic Alliance led by the United States. They have focused on the socio-economic reconstruction and development of integration processes. The US was carrying out two strategic tasks: 1) securing Europe against possible threats of a German militarism renewal and from continental conflict; 2) consolidating NATO for the confrontation with the USSR. The alliance between the United States and Great Britain, which was symbolizing the Atlantic solidarity in

${ }^{1}$ S. Erlanger, Eastern Europe Frets About NATO's Ability to Curb Russia, The New York Times 2014, April 23. 
Western countries confrontation against the Soviet bloc led by the Soviet Union, for more than four decades has been carrying the burden such as organization and furnishing the security system in Western Europe. London has historically performed a central role in transatlantic relations, promoting the communications of its two poles (North American and European) ${ }^{2}$. The UK opposed the French idea of creating a European military force with supranational authorities that was provided by Paris Agreement in 1952 on the European Defence Union. London was insisting on maintaining the priority of NATO in the security questions and put forward an alternative project of creating a satellite Alliance to the Western European Union (WEU). The main mechanisms of guaranteeing the European security were passed to the US. In terms of global bloc confrontation it was strategically justified.

At the instigation of British politicians (especially Winston Churchill) the USBritish relations had received the stamp of "especials", that in modern political and expert circles got quite broad and usually ambiguous interpretation. Washington hoped that the United Kingdom, with its existing significant military and political capabilities (while being actively involved in the anti-Soviet confrontation, culturally and historically pro-American, and economically anti-protectionist), could become an influential member or even a leader of the united Europe ${ }^{3}$. Largely thanks to the diplomatic pressure of Washington, London, while having illusions of global status on the background of the farewell to the empire and the historical and cultural detachment from Europe, in 1973 had gained full membership in the EEU. During Thatcher's government the United Kingdom supported the development of political cooperation within the EEU at the international level by using the mechanism of European Political Cooperation in their international interests, but opposed the formation of its political and military segments. Such position did not meet the new tendencies of US foreign policy, which at the stage of completion of the "Cold War" were more interested in the willingness of the European flank of NATO to make an effective contribution to its own security.

In 1989-1991 after the collapse of the USSR and the OWA (The Organization of Warsaw Agreement), Western countries had found themselves in double circumstances - the euphoria from winning the bloc confrontation and the security vacuum in geopolitically disoriented eastern and southern areas of Europe that

2 I.A. Cyr, Europe and the United States: Change and Continuity, International Affairs 2012, no. 88:6, p. 1315.

${ }^{3}$ R. Harris, D. Phil, Britain and Europe: Where America's Interests Really Lie, The Heritage Foundation 2013, Special Report no. 131 on Europe, April 29, http://www.heritage.org/research/ reports/2013/04/britain-and-europe-where-americas-interests-really-lie (accessed 16.04.2015). 
immediately became a conflict-prone environment. According to Robert Cooper, the events of this period meant not only the end of the Cold War, but also of the system of power balance in Europe ${ }^{4}$. Geopolitical changes in the early 1990s pushed the United States, NATO, and the EU to make an existential choice - to save the status quo in the European security system or to form a new international policy, supported by new regional resources. One of the attempts to make this choice was developing within the EU the Common Foreign and Security Policy (CFSP) and the European Security and Defence Policy (ESDP) as its component. However, the expansion of the European community priorities on the security and defense caused a corresponding reaction of NATO, which secured the concept of a European defense identity (EDI) in the Strategic Concept in 1991. The agreement determined only the general direction of the future development of the military-political integration of the EU, but the formulation of CFSP resulted in discrepancies of its tasks and implementation peculiarities. The safety constituent part in the system of integration has led to the interstate compromise nature of integration discourse of the established concepts, which are eurocentric (the leaders are France and Germany) and Atlantic (Great Britain, Denmark, the Netherlands, and others). And the prospect of its implementation was postponed to the next cycle of institutional and legal changes. At the insistence of the British government, the structures of WEU became the basis of the ESDP. As a result, the initiatives mentioned above were directed to the Atlantic (pro-American) concept of the European support of NATO. The compromise content of the agreement in the part of ESDP was convenient for the UK.

In the first half of the 1990s the European Union in general was showing some interest in security issues, focusing on the questions of the common market. The initiative in the military questions was actually given to the limited WEU structures, which, with the support of NATO, began the implementation of the new concept on the basis of the humanitarian and peacekeeping "Petersberg tasks", adopted in June 1992. The structures of the Alliance continued to carry out the main strategic tasks, such as guaranteeing safety and collective defense. NATO's decision on the development of EDI and the foundation of Multinational Common Operative Forces in Europe showed the desire of the US to prevent the separation of the European cooperation plans from the Atlantic. The UK, like the US, did not take the EU as an influential international actor who could be able to achieve military and political influence.

${ }^{4}$ R. Cooper, The Breaking of Nations: Order and Chaos in the Twenty-First Century, London 2003, p. 8. 
In the conditions of the Eastern threat liquidation in Europe and the start of the implementation of a full-fledged EU foreign policy, there was still a question of appropriateness; for the United States it was also the question of the price of total further reliance of Europe in the field of security and defense. The United States began to shift the priorities and political-military resources to resolve and prevent the security challenges in the regions of Central and Southeast Asia and the Middle East. As a result, American military presence in Europe decreased from 300 to 80 thousand peoples. NATO began to form the Rapid Response Forces in the conditions of the disappearance of the threat of total war with a wide theater of hostilities on all fronts. However, at the beginning of the 1990s, the Balkanian War events had showed that the EU cannot solve the urgent problems of security on their own borders without the decisive influence of the US and NATO. As a result, the association had to intensify practical work on the development of the project of ESDP.

The United Kingdom throughout the whole period of the post-bipolar geopolitics remained faithful to the Atlantic commitments and was supporting the idea of preserving the leading role of NATO in the European security. Finally, London did not meet much resistance in such a policy, maybe with the exception of the always ambitious Paris, which traditionally wanted the autonomy of the European military-political structures. CFSP impartially is a field of European integration processes, where London's position has the maximum impact on the policy and the regulatory and functional system of the EU. An active part in the discussion of strategic questions and periodic support of certain innovative initiatives remains the main tactical instrument of the British policy in the EU. Its main aims are to intercept the strategic initiative in the Federalist "core" - Germany (FRG) and France, and to control the development process of political integration from the inside to preserve the status quo in the transatlantic security system. However, during the second half of the 1990s, there was a gradual evolution of the fundamental position of Great Britain in relation to the military and political dimension of the EU, from categorical anti-European rhetoric and radical Atlanticism to active participation in the European political integration, through the efforts to take a leading position and to affect the dynamics and meaning of the unification processes. The desire to strengthen the state influence on the European processes of John Major and especially Tony Blair's governments, in terms of refusal to enter

${ }^{5}$ A. Sytas, A. Croft, Insight - Ukraine Crisis will be "Game Changer" for NATO, Brussels 2014, May 18, http://www.reuters.com/article/2014/05/18/us-ukraine-crisis-nato-insight-idUSBREA4H 01V20140518, (accessed 28.04.2015). 
the Euro zone and also the gradual reorientation of the US foreign policy priorities, subserved such evolution.

The signing of the British-French declaration in St Malo in 1998 was a progress in the military-political integration of the EU, which initiated the process of establishing autonomous European armed forces. The document provided the cabilities for the Union to act by military means to resolve international crises, where NATO was not involved, and to transfer the WEU functions to the structures of the EU. Although the British government made the concessions, that did not mean changing the key principle of modern foreign policy, i.e. preserving the Atlantic solidarity on the basis of the US-British "special relations". Talking about fundamental issues, London has always been on the side of Washington. Thanks to London's position, the Paris initiative on the formation of the European army was vetoed during the preparation of the Nice Agreement in 2001. Transformation of the Labour government position in the question of the military resources of the United Europe reflected the political hesitation of the US government on the possibility of the development of the European military units that were considered as part of strengthening the capacity of the European segment of NATO. British initiatives on the development of European security structures formed the basis for the cooperation between the EU and NATO on the basis of "distribution of powers", embodied in the agreements "Berlin plus agreement" of 2003.

As the development of international relations system in Europe at the turn of $20^{\text {th }}$ and $21^{\text {st }}$ century has showed, Western countries in the post-bipolar period made two main strategic mistakes. The first one was the fact that, since the EU foundation, the development of its defensive resources, which are formally provided in the constituent acts, has slowed dowm. The union was kept in its traditional condition of strategic military-political and military-technological dependence on NATO and the United States. In comparison, in 2012, US military spendings were 682 billion US dollars and the spendings of 26 EU Member States (with the exception of Denmark) were 189.6 billion US dollars ${ }^{6}$. Deprived of the strategic means of direct military influence, the European Union, in the terms of ESDP, is preserved as a NATO supporting organization with amorphous and limited functions of conflict prevention, police regulation in post-conflict areas, and humanitarian aid. NATO has kept the function of the striking force in solving military conflicts. The EU was actually deprived of its own operative staff management by including the EU Operations Centre into the structure of the NATO Common

${ }^{6}$ Trends in World Military Expenditure 2012, SIPRI, April 2013, p. 2; Defence Data 2012, ed. E. Platteau, Brussels 2013, p. 4. 
Forces Staff in Europe. Taking into account the power of nation-selfishness, a lack of economic opportunities, and opposing international interests, EU countries are not able to form an international center of power within the structures of the association for its own operational protection. The EU in its actions depends on the political will and resources of the "big three" countries (Great Britain, France, and Germany). The Big Three's percentage share of EU expenditures is more than $60 \% 7$. Only the United Kingdom and France have sufficient military resources for their own defense and possible deployment of forces outside the continent.

The United States, which at the beginning of the $21^{\text {st }}$ century with the gradual loss of its status of global hegemony, are aiming to transfer more power in protecting the borders of Europe to the Europeans. As a result, they have met their strategic inertia and focused on their own short-term interests. The US are forced to reap the benefits of the long-term controversial policy on the development of autonomous opportunities of the European security policy, while being in a permanent role of "first-aid" for the settlement of problems in the center and near the periphery of Europe (conflicts in the Balkans, Somalia, Libya, Syria, during the events of the "Arabian spring", and in Ukraine). Europe is still de facto a military protectorate of the United States ${ }^{8}$. The asymmetry of the US-European military-political opportunities is also visible in NATO, where the US provides three-quarters of the expenditures. As of the 2013, the defense expenditures of the European countries, comparing with the period of the first half of 1990, were cut down from $2,5 \%$ to $1,6 \%$ of GDP. A similar US index remains on the level of $4 \%$ of GDP'. The economic recession has complicated the prospects of European defense programs. These trends have led to the point where Europeans are not able to defend themselves against military aggression.

Partially, this situation is linked with the unilateralist policy of the American government of the times of George W. Bush's leadership. By its unilateral actions in the international arena, with bypassing the international normative order, it had undermined the international prestige of the US and had not only provoked the conflict in the ranks of the old members of NATO and the EU, but underlined and outlined the strategic differences between them and the new member states of these organizations from the region of Central and Eastern Europe. US military action in coalition with European allies (especially the UK) in Iraq opened the

\footnotetext{
7 S. Lehne, The Big Three in EU Foreign Policy, Washington 2012, p. 4.

8 3. Бжезінський, Україна у геостратегічному контексті, Київ 2006, p. 14.

${ }^{9}$ L. Mangasarian, Putin Emboldened on Instability Arc by EU Defense Divide, Bloomberg 2014, May 15, http://www.bloomberg.com/news/articles/2014-05-14/eu-east-west-defense-divide-emboldens-putin-s-arc-of-inst, (accessed 1.05.2015).
} 
"Pandora's box" for the actions of other influential international power centers, especially Russia, in the regions of geopolitical priority.

The second miscalculation is the fact that the Western Allies ignored the important spaces for the continental geopolitics of Eastern Europe, i.e. countries of the former USSR. The former Soviet Union's republics, first of all countries between Russia and the EU, including Ukraine, have received the status of the relatively successful buffer territories with the prospects of democratic development. The US and Western Europe actually farmed out to Russia the territories of its traditional geopolitical influence (except the Baltic States) with the condition of implementing free market economy and democratization of social relations and the form of statehood. The Western world believed or really wanted to believe that a weakened Russia abandoned its imperial aspirations. The joining of Central European countries and peripheral countries of the former Soviet Union with the domination of Russia did not exclude the influence of Euro-Atlantic values and standards of public life upon them.

In the first decade of the $21^{\text {st }}$ century there have been changes in international relations related to the crisis of the American hegemony in the world politics and the formation of a multipolar system of international relations in conditions of strengthening the regional centers of power with global ambitions (the EU, China, Russia). Let's distinguish a number of factors that supported the strengthening of Russia's positions in the international arena. There was a change of the ruling elite due to the retirement of the old Soviet party and a shift of the economic nomenclature to the latest oligarchy period of "wild capitalism". The other reason was also the coming to power of a cohort of former employees of the Committee of State Security (CSS) of the USSR and other security agencies and loyal to them top-ranking bureaucracy, which was heading for the centralization and the establishment of an authoritarian system of government. Thus the system of denationalizational and capitalism with total control of big business by the state was formed. Such companies as "Gazprom","Rosneft", and others became not only an integral segment of the foreign trade of the country, but also the realization of geopolitical ambitions of the ruling elite. The filling of the budget with petrodollars in terms of favorable trends in the global energy market created the opportunities for the militarization of the economy with an overall low level of life that has become the part of the myth of the country's power. In 2012 the military expenditures have put Russia in the third place in the world after the US and Chi$n a^{10}$. In comparison, Central and West European countries cut defense spending

10 Trends in World Military Expenditure 2012, SIPRI, April 2013, p. 2. 
by $6,5 \%$ between 2004 and 2013 while Russian military spending doubled over that period ${ }^{11}$.

The international political situation was favorable for Russia. The split in the ranks of NATO due to the unilateral initiation of the Iraq war by George. W. Bush's administration made it possible for Vladimir Putin to get close to the leaders of France and Germany. Russia has strengthened its political and economic relations with a number of EU countries by successful energy management through the supply of Russian gas and enlarging the business interests. The focusing of Western states and organizations on their own economic problems, EU institutional and political problems and certain stagnation in NATO activity due to the uncertainty of future strategic orientations of the organization have caused the weakening of attention and indulgent attitude of the democratic world to the growth of authoritarianism and a total attack on the democratic values in Putin's Russia against a background of the growing revanchist attitudes in the foreign policy. According to Vladislav Inozemtsev, the USSR collapse, in the foreign policy of Russia, is regarded as the "geopolitical catastrophe of the $20^{\text {th }}$ century", and the sovereignty of the post-Soviet countries is considered essential ${ }^{12}$. The success of "coloured revolutions" in Georgia, Ukraine, and Kyrgyzstan, the replacement of the ruling Communist Party by the pro-European forces in Moldova, the completion of the admission of the Central European and Baltic states to NATO and the EU, the startup of the European Missile Defense System program were taken by the Russian leadership as a violation of status quo in the post-bipolar balance of power in favor of the US and its allies and the attack on Russian influence in the region.

Reviving long traditions of autocratic imperial thinking, reinforced by the extreme manifestations of nationalism and xenophobia, Putin's regime under the pretext of protecting the interests of the state and the rights of Russian-speaking population in the former Soviet republics, took the course of open economic, diplomatic, and later military intervention in neighbouring states. As the famous German expert on the development of modern Russia Boris Reitschuster declares "in spite of all the fake optimism, twenty years after perestroika the democracy in Russia has collapsed"13.

The process of developing the consolidated policy of the states and institutions of the Euro-Atlantic community is complicated by the heterogeneity of

${ }_{11}$ A. Sytas, A. Croft, op. cit.

12 В. Иноземцев, Потерянное десятилетие, Москва 2013, р. 587.

13 B. Reitschuster, Putins Demokratur: Ein Machtmensch und sein System, Berlin 2014, p. 26. 
the position of its subjects. Political elites of the EU leading countries, especially France and Germany, while being the supporters of multipolar system of international relations are implementing hidden intentions to balance the excessive US influence on the European affairs through the pro-Russian policy. In particular, the Franco-German tandem vetoed US-British initiative on the adoption of the Action Plan for Georgian and Ukrainian NATO membership at the summit in Bucharest in April 2008. The consequences of such a policy are the implementation of a planned military intervention of Russian troops in Georgia in August 2008. Western allies have not developed a common political course towards Russia.

This signal was rejected by all the Western allies. US President Barack Obama had not learnt a lesson from the recent Russian-Georgian war and in 2009 he announced the "restart" of US-Russian relations, which were accompanied by a decrease of US involvement in European affairs, and actually with ignoring the post-Soviet area. On 8 April 2010 the Strategic Arms Reduction Treaty (START) between the US and Russia was signed in Prague. The US refused to place Missile Defense System stations in the Czech Republic and Poland. This policy proved the agreement of the West on the priority right of Russian control in the region and as a result the international ambitions of Russia were roused.

The weakness of the West, especially the EU, in relations with Russia are clearly manifested during the events of its military aggression on the territory of Ukraine. The annexation of Crimea in March 2014 brought an international condemnation, but had no significant consequences for the aggressor. First of all, Europe and the US have shown unreadiness to conflict development in Eastern Europe when they started the formation of a real strategy to fight during the deployment of Russian full-scale unofficial intervention in the Ukrainian Donbass. After lengthy hopes of diplomatic policy of appeasement the aggressor, the EU Council has finally taken the decision to impose systemic sanctions (aka "third wave" sanctions), but only after the tragedy of the Boeing 777 liner in the Donetsk region in July, and then the entrance of the regular units of the Armed Forces of the Russian Federation into the territory of the region on the Independence Day of Ukraine on 24 August 2014. On 1 September the newly appointed High Representative of the Union for Foreign Affairs and Security Policy Frederika Mogherini announced the termination of the EU partnership with Russia. The possibility of using military or policy resources of the EU is out of the question. In terms of defense, the Union can not offer anything to Ukraine but the traditional methods of "soft power", such as non-effective diplomatic support, the Association Agreement, the prospect of economic aid, and anti-Russian sanctions that will have long-term 
consequences. The irony of "soft power" is that it so often requires "hard power" policies to become effective ${ }^{14}$.

Before the NATO summit in Wales on 4-5 September 2014 Secretary General of NATO Anders Fogh Rasmussen had made a historic statement that NATO and Russia are no longer partners but opponents. The reality of the returning to the "Cold Was" is more than ever relevant. Due to the geopolitical characteristics, Ukraine is not a country that needs a regular expression of disquietude on its intervention. In modern conditions that alliance is an effective ally of Ukraine only in the defense against aggression from the East. The clear position of the US and some other countries (including the UK) from the first days of the conflict, their diplomatic, military, technical, intelligence, and humanitarian assistance were crucial impetus for the gradual formation of appropriate positions and specific actions of the states and institutions in continental Europe in terms of the escalation of the Russian-Ukrainian conflict. However, none of the partners of Ukraine is in a hurry to provide offensive weapons in hopes of de-escalation of the conflict. The Multilateral Budapest Memorandum on Security Assurances, due to the Ukraine's accession to The Treaty on the Non-Proliferation of $\mathrm{Nu}$ clear Weapons from 5 December 1994, where one of the parties was the United Kingdom, was not worth the paper on which it was written. No one is ready for a full-scale war in Europe.

The events in Ukraine actually have led to another division of the EU, this time in terms of loyalty to the Russian policy. The anti-Russian group includes the United Kingdom, Sweden, but first of all the Baltic States, Poland, and Romania. The latters are the potential targets of the Russian aggression. However, the proRussian lobby does not stop working in the EU and NATO. Still, Austria, Italy, Finland, Hungary, and Slovakia opposed a proposal of the introduction and later of the prolongation of the sanctions. Almost the entire democratic world is convincing French President François Hollande to refuse to sell the Mistral-class aircraft carriers. In September 2014 at the height of the Russian aggression in Eastern Ukraine, the EU Commission took a decision to delay the entry into effect of the Free Trade Agreement between the EU and Ukraine for the purpose of satisfying Russian economic interests. Europe is too slow from the captivity of pro-Russian illusions to see clearly and is afraid of the future without Russian gas supplies. Even under the existing threats for Euro-Atlantic security, the EU and NATO are not ready to give Ukraine a clear perspective of membership.

${ }^{14}$ K. Nielsen, EU Soft Power and the Capability-Expectations Gap, Journal of Contemporary European Research 2013, Vol. 9, Iss. 5, pp. 723-739. 
Many Europeans still retain the faith in the possibility of a return of Russian modern policy in the limits of international law and diplomatic appeasement of geopolitical ambitions of its leadership. The main problem of the EU is evident in the words of President of the European Council Herman van Rompuy, who in May 2014 made a statement that the EU does not seek to expand its influence in Ukraine, because "the EU has no geopolitical ambitions and it works quite differently than the Russian leader"15. This statement reflects the political reality, in which the EU did not want to conduct a dialogue with Russia in the language of geopolitics and had never publicly acknowledged the geopolitical rivalry with Russia in Eastern Europe. British journalist Edward Lucas in his work The New Cold War states that "the confrontation offers the same chance of new relations with Russia, based on realism, not sentiments, sobriety thinking instead issuing wishful thinking. Subsequently, the price will be higher - perhaps so high that the West no longer be able to pay it" ${ }^{\prime \prime 16}$.

The fact of the NATO Summit on 4-5 September 2014 in the UK during particularly difficult time for the Alliance and the entire Euro-Atlantic security is very symbolic, as this country is the second subject of the organization while talking about the expenditures and capacity. Among the leading countries of NATO, except the US, the UK provides a certain minimum level of defense spending to $2 \%$ of GDP. At the same time, as noted by Sven Biscop, the problem of European defense is that it can not operate with the United Kingdom, but also can not fully function without $\mathrm{it}^{17}$. According to the European Defence Agency, the UK remains the leader of the development of European defense expenditures $(2,5 \%$ of GDP $)^{18}$. The country is one of the four EU countries who provide military personnel and shares the first place with France in the number of troops allocated. Almost all of humanitarian missions or peacekeeping operations of the EU do not occur without the participation of British experts. At the same time, while maintaining a high average level for providing ESDP of EU national expenditures, the policy of the British leadership in this field of European integration is experiencing stagnation and crisis, as actually its whole European policy since the Conservatives came to power in 2010 .

${ }^{15}$ H. Van Rompuy, EU hegt keinerlei geopolitische Ambitionen, Frankfurter Allgemeine, 21.05.2014, http://www.sanalbasin.com/van-rompuy-eu-hegt-keinerlei-geopolitische-ambitionen-5043738, (accessed 1.05.2015).

${ }^{16}$ E. Lucas, The New Cold War: Putin's Russia and the Threat to the West, New York 2014, p. 268.

${ }_{17}$ S. Biscop, The UK and European Defence: Leading or Leaving, International Affairs 2012, no. 88:6, p. 1297.

18 S. Guzelyte, National Defence Data 2012 of the EDA Participating Member States, Brussels 2014, p. 4. 
Even in the pre-election period the Conservatives, who took the key positions in the government on foreign policy and security questions, to counterbalance their pro-European coalition colleagues the Liberal Democrats, declared pragmatism and a review of these relations in order to prevent further association federalization. As for the CFSP of EU, David Cameron in public pre-election speeches tried to avoid the European topics. The Euro zone crisis deepened British euroscepticism. In the election manifesto of the party there is a paragraph on inappropriate government spending on the EU bureaucratic initiative on defense. There is a functional paradox. During the reign of the coalition government, the UK has traditionally played an active role in the development and implementation of EU foreign policy decisions, but CFSP, especially CSDP, is offered by association as one of the areas of cost reduction. The British government raised the question of funding cuts of the European External Action Service, the European Defence Agency, and the EU Military Staff. At the EU summit in Brussels on 20 November 2013 David Cameron stated unequivocally that London will block any initiative on the creation of united forces of the European Union ${ }^{19}$. The UK withdrawal from the EU on the results of the referendum which will be held no earlier than in 2017 can bring irreparable harm to the international position of the country and the European security system. In an effort to review the conditions of membership, the government hopes to get the opportunity to determine the priority areas of the participation in the Union, and the CFSP of the EU is among them.

Due to the European isolationist policy and the weakening of the British position in the EU, there is a reduction of the attractiveness and reliability of the country in the eyes of American politicians, who were so zealously trying to keep all British governments. In previous years, the United States had an interest in controlling and encouraging the European allies in the integration development with the purpose of not permitting excessive strengthening and their independence what the UK was actually doing pretty well. But in the present conditions America's priorities have changed in favor of increasing the responsibility of the Europeans for their own security, which is impossible without deepening integration. The military operations in Libya in March and October 2011 have proved it. The US is particularly concerned about the complex reduction of the defense budget of Great Britain. The fall back of London because of the possible withdrawal from the EU would deprive Washington of a convenient tool of exerting

19 European Council December 2013: David Cameron's press conference. Brussels, 20 December 2013, https://www.gov.uk/government/speeches/european-council-december-2013-davidcamerons-press-conference (accessed 30.04.2015). 
influence in Europe. Barak Obama stated very clearly that a strong UK in a strong Europe is in America's national interest ${ }^{20}$.

The analysis of the European policy of the current government gives every reason to suggest that the United Kingdom is losing a real opportunity to lead the European integration process in the field of foreign and security policy in the condition of general crisis in the EU. At the same time, Germany, which expands the traditional sphere of influence in the Balkans and in Eastern Europe, has an increasing influence within the CFSP. And also France puts forward claims for leadership in the EU's relations with the countries of the southern Mediterranean. The separation of the British government from major European issues, in particular, the unilateral migration limit of the labour force which was introduced on 1 January 2014, has turned away the traditional supporters of the UK, i.e. the countries of Central Europe.

In such circumstances, Russian military aggression on the territory of Ukraine and the associated consequences for the European security system have objectively given a new chance for the European and Euro-Atlantic politics of the UK to restore the international positions and to turn the international relations and security system in the region into a favourable channel. The government of the country during "the Revolution of Dignity" was supporting the European choice of Ukrainian people and urged the then leadership of Ukraine to restore their course of European integration. From the first days of the aggression of the Russian troops in Crimea, the UK had strongly condemned Russia's actions and supported the initiative of its exclusion from a number of international organizations, including the G8. An insignificant dependence on Russian energy, in comparison with other EU states, uneasy political relations with the Kremlin, the opportunity to overcome the cooling in relations with the United States against the background of the formation of the effect of another "mutual enemy", and the desire to strengthen the position of NATO and the EU have allowed the leaders of the country to enter upon the path of open criticism of the actions of Russian leadership. London was one of the initiators of the EU sanctions against Russia and was among the first to express readiness to provide financial and military-technical assistance to Ukraine. The British government took an advantage of the moment to restore influence in Central Europe by acting as a member of the formation of NATO's new military units. In order to hold back the Russian aggression, there are plans to relocate up to 20 thousand of British troops from Germany to Poland

\footnotetext{
${ }^{20}$ R. Harris, D. Phil, op. cit.
} 
and the Baltic countries as divisions of "permanent presence"21. At the NATO summit in Wales it was decided to establish a multinational Rapid Response Forces with the participation of the United Kingdom.

Meanwhile, there are still some double standards in the British foreign policy. The Committee on the Export Control of arms of the House of Commons of the British Parliament in July 2014 has released the information about the effect of the contracts for exportation of British weapons to Russia. In the midst of the war there were still 251 active licenses on the export of the respective goods to Russia on a total sum of 225 millions USD. Only 31 licenses were suspended. The British media published the information about the facts of financing the election campaign of Conservative Party by one of the British firms, the management of which is connected with the Russian capital and has ties with the Kremlin ${ }^{22}$. Despite the strenuous political relationship between the countries in the last decade, there is a significant impact of the Russian lobby on the social and political circles and on the business elite of the United Kingdom.

The events of the Russian-Ukrainian conflict were the subject of the great geopolitical game in the EU and NATO for the influence over the Eastern policy, including the informal competition between Great Britain and Germany. At the end of July 2014, the British magazine "Independent", on the basis of the information from its own sources, revealed the existence of a secret plan-agreement between Angela Merkel and Vladimir Putin to resolve the conflict in Ukraine, which included the recognition of the annexation of Crimea and refusal of Ukrainian entry to NATO. This plan was allegedly never realized because of the accident of Malaysian airliner over the Donietsk Region ${ }^{23}$. German authorities somewhat later denied this information. Meanwhile, German authorities who are traditionally strongly linked with Russia through business interests, have seriously thought over enlarging their military resources in response to Russia’s actions ${ }^{24}$.

${ }^{21}$ M. Hookham, British Troops to Deter Russians, The Sunday Times 2014, 3 August, http:// www.thesundaytimes.co.uk/sto/news/Politics/article1442320.eceBritish\%20troops\%20to\%20 deter\%20Russians (accessed 28.04.2015).

22 O. Wright, Exclusive: Tories under Fire for Links to Pro-Russia Lobbyists, The Independent 2014, 3 July, http://www.independent.co.uk/news/uk/politics/exclusive-tories-under-fire-for-linksto-prorussia-lobbyists-958302 3.html (accessed 1.05.2015).

${ }^{23}$ M. Pagano, Land for gas: Merkel and Putin Discussed Secret Deal Could end Ukraine Crisis, The Independent 2014, 31 July, http://www.independent.co.uk/news/world/europe/land-forgas-secret-german-deal-could-end-ukraine-crisis-9638764.html (accessed 2.05.2015).

${ }^{24}$ C. Copley, German Army to Procure More than 100 Additional Leopard 2 Tanks, Berlin (Reuters), 10 April 2015, http://www.reuters.com/article/2015/04/10/us-germany-defence-tanks-idUS KBN0N11A920150410?feedType=RSS\&feedName=w11/06/orldNews (accessed 29.04.2015). 
The events in Ukraine gave the opportunity for resuscitation of the AngloAmerican "special relationship", which is experiencing hard times due to the differences in the number of international interests and because of common pragmatism. The vote of the British Parliament on 29 August 2013 against the draft of the government decision on the participation of the armed forces in Syria bombardment was the culmination of the British post-Iraqi syndrome. The emergence of the international threat from Russia to the Euro-Atlantic alliance can restore the traditional scheme of alliance between London and Washington with an aim to dominate the European security system.

Thus, the Russian-Ukrainian conflict can be a powerful stimulus for the development of NATO during the period of comparative stagnation of the organization development during the first decade of the $21^{\text {st }}$ century. The Alliance finds its calling in military presence in Europe, which it has lost at the end of "the Cold War". The renaissance of the dangerous and aggressive opponent such as modern Russia, who has got significant and varied arsenal of weapons, has arisen largely from the connivance of most Europeans and Americans and because of the failure of their policies in Eastern Europe during the last two decades. The reactivated Russian threat to European and Euro-Atlantic security will partially turn the attention of NATO (the US) to the European area. The main function of the Alliance is again containment of the wars in Europe. It will signify the necessity of the reorientation of its military power to perform complex defense tasks and to increase the readiness for a big strategic confrontation. There is a necessary shift of the preferences for the defense in the region of Central and Eastern Europe.

It may seem paradoxical, but European reorientation of NATO and the US is advantageous for Europeans as they did not find the opportunities to organize themselves for their own collective security and defense during the period of comparative absence of direct military threats. The Russian military aggression against Ukraine has shown that the European security strategy during the last two decades has suffered a defeat. The European Union could not and also did not want to form the military opportunities to secure and defend their international interests. The EU had preferred the traditional security assurances and failed the policy of "Eastern Partnership" with its strategic limitations. The time when Europeans shut their eyes to the development of an authoritarian dictatorship in Russia, enjoying their own pacifist and democratic values in their warm homes, which were warmed by Russian gas, came to an end. At the same time, the nature and the level of US leadership have changed. The United States are not completely ready to secure European security and are needing more and more funds for their own defense in terms of strong threats from the Arab East and China to their powerful global influence. 
The international crisis for Great Britain due to the Russian-Ukrainian conflict for the umpteenth time underlines the need to solve its traditional geopolitical dilemmas, i.e. to continue to be guided by the United States foreign policy or to conduct a more independent policy, also to stay in the United Europe and try to become the leader of the political integration with the US support, or try to realize international ambitions beyond its institutional boundaries. The state governments of different periods are involved in the strategic political and military weakness of the United Europe and the dependence on the United States. Cherishing the idea of Atlanticism, London during over half a century did not review the EEU / EU as an effective mechanism for resolving security problems and is still hindering the creation of a European army and the enlargement of the EU competence in the field of defense. Great Britain has traditionally made a bid for the role of the main ally of the US and "the megaphone" of Washington in Europe. We believe that this is limiting the international influence of the UK.

The crisis of the European security as a result of the Russian-Ukrainian conflict and changes in the system of international relations are favourable for the UK because of its main foreign policy interests: 1) there is a partial European reorientation of NATO and the US; 2) the attention of Europeans is shifting from the development of the EU military-political opportunities such as CSDP to the traditional Atlantic structures of continental security; 3) there is an opportunity to restore the foreign political influence of the country in Central and Eastern Europe and in the whole European Union.

The aggravation of the international confrontation in Eastern Europe makes the necessity for preserving the unity and effectiveness of the transatlantic security system more urgent than ever, as well as transferring it into a new qualitative level. At the same time, we should not forget that the CFSP of the EU became an essential segment of this system. Despite the global positioning and status of the first US ally, Great Britain has no real alternatives to saving the position of a full member of the European Union as well as to a maximum integration in its structure. Still, the UK retains the possibility to become a leader, especially in the area of foreign and security policy, as the crisis of 2014 has shown. The US through NATO remains the guarantor of the functioning of the Atlantic security system. Its efficacy increasingly depends on the real contribution of its European component. Therefore, it is a high time for the United Europe and the UK to reconsider their attitude to regional security and to stop looking back at the transoceanic partner. 